\title{
EFFICIENCY OF ELECTROFISHING AS A SAMPLING METHOD FOR FRESHWATER CRAYFISH POPULATIONS IN SMALL CREEKS
}

\author{
F. Alonso \\ Centro de Investigacidn Agraria de Albaladejito. Servicio de Investigacidn Agraria. Junta de Comunidades de \\ Castilla-La Mancha. Cta. Toledo-Cuenca. Km 174.E-16194.Cuenca. SPAIN
}

\begin{abstract}
SUMMARY
A total of 56 successive depletion electrofishing surveys were carried out on Austropotamobius pallipes (Lereb.) populations from June 1997 to June 1998, in three small Spanish creeks. Some adaptations of the technique to crayfish sampling were using a low voltage $(30-50 \mathrm{~V})$ output, fitting a net on a square shaped-anode, a very slow upstream progression of the fishing team and hand-catching narcotized crayfish. Mean overall catchability was $\mathrm{p}=0.603$, with catches amounting to an average $93.90 \%$ of the estimated population number. Crayfish smaller than $40 \mathrm{~mm}$ TL comprised a significant proportion (31.25\%) of the catch. Catchability was found to increase with crayfish size. No significant differences in catchability were found between sexes. Cheliped loss was observed in $26.75 \%$ of the individuals captured. This proportion decreased significantly with total length, as did the proportion of individuals suffering loss of both chelipeds. High cheliped loss remains as a major disadvantage of this technique. Nonetheless, our data suggest that electrofishing can be regarded as an effective tool for sampling crayfish populations in this kind of habitats, although its use is scarcely reported.
\end{abstract}

Keywords: white-clawed crayfish, Austropotamobius pallipes, electrofishing, catchability.

\section{RESUMEN}

Se han realizado 56 muestreos sobre poblaciones de cangrejo autóctono Austropotamobius pallipes (Lereb.)en tres arroyos entre junio de 1997 yjunio de 1998. El método empleado fue el de capturas sucesivas sin devolución mediante pesca eléctrica. Entre las modijicaciones aplicadas sobre las técnicas rutinariumente empleadas en el muestreo de peces resefiaremos: el empleo de bajos voltajes de salida (30-50 V), el uso de un ánodo cuadrangular provisto de una malla de captura, una progresión muy lenta del equipo de muestreo, y la capturu manual de gran parte de los cungrejos narcotizados. La capturabilidud media fue de $p=0.603$, y las capturas totales supusieron en promedio el $93.90 \%$ de la poblacidn estimada. Los individuos de pequevio tamavio $(L T<40 \mathrm{~mm})$ componen una apreciuble proporcidn $(31.25 \%)$ de la capturu total. La capturabilidad aumentó con el tamaño de los cungrejos, no encontrundose dijerencias significativas en la capturabilidad entre sexos. Se observó pérdida de algdn quelípedo en el $26.75 \%$ de las capturas, porcentaje que disminuye significativamente con la longitud total, al igual que sucede con la proporcidn de individuos que perdian ambos quelípedos. Este elevado grado de mutilación se identifica como el principal inconveniente de la técnica. Pese a ello, nuestros datos sugieren que la pesca eléctrica puede ser considerada eficaz para el muestreo en este tipo de hábitats, aunque rara vez se citu su uso.

Palabras cluve: cangrejo, Austropotamobius pallipes, pesca eléctrica, capturabilidud

\section{INTRODUCTION}

The white-clawed crayfish Austropotamobius pallipes (Lereboullet, 1858) is the only freshwater crayfish species native to Spain. During the last three decades it has become threatened with extinction due to the spread of aphanomycosis, the expansion of introduced crayfish populations, habitat loss and poaching (Temiño et al., 1987; Carral et al., 1993, Diéguez-Uribeondo et al. 1997b, Alonso et al.,2000). Most of the surviving populations are found in short stretches of very small streams, usually cut off from the main river systems during the summer drought period.

Lack of data on the biology and ecology of these isolated populations emphasizes the need of 
developing reliable quantitative sampling techniques for this kind of habitats, in order to develop sound conservation and restoration programs for the species (Diéguez-Uribeondo et al.,1997a)

Baited traps are the most widespread method for quantitative estimation of freshwater crayfish populations. Nonetheless, several authors have pointed out the limitations of trapping to estimate absolute population numbers (Abrahamsson, 1966, 1983; Brown \& Brewis, 1978; Westman et al., 1979; Fenouil \& Leger, 1988; Hogger, 1988; Westin \& Gydemo, 1995). These are mainly related with size, moulting stage, sex and reproductive stage selectivity and its variation along the year, the typically low recapture numbers of marked animals, and the problems associated to the modelling of capture-recapture data, particularly in geographically open populations (White et al., 1982). In shallow creeks, additional problems arise such as finding representative locations for traps, or making easier the location of populations by poachers.

A few number of works report the use of electrofishing on freshwater crayfish populations, either for quantitative sampling (Demars, 1979; Bernardo et al., 1997, Rabeni et al., 1997), or more frequently as a way for gathering qualitative information or collecting individuals otherwise non-accessible to the sampling methods more commonly used (Jestin, 1979; Westman et al., 1979,1986, 1993; Almaça, 1989; Ilheu \& Bernardo, 1997; Gutiérrez-Yurrita et al., 1997). As far as we know, only Bernardo et al. (1997) and Rabeni et al. (1997) have provided some information on the efficiency of the technique on any freshwater crayfish, the formers working also on Austropotamobius pallipes, and the later ones on koura crayfish, Paranephrops planifrons. Also some quantitative work has been done in tropical streams on freshwater shrimps of the families Atyidae and Palaemonidae (Penczak \& Rodriguez, 1990; Pringle \& Blake, 1994; Fievet et al., 1996).

In this work we analyze the data obtained during an ongoing monitoring programme to estimate the efficiency of electrofishing on freshwater crayfish, study its variation with size and sex,

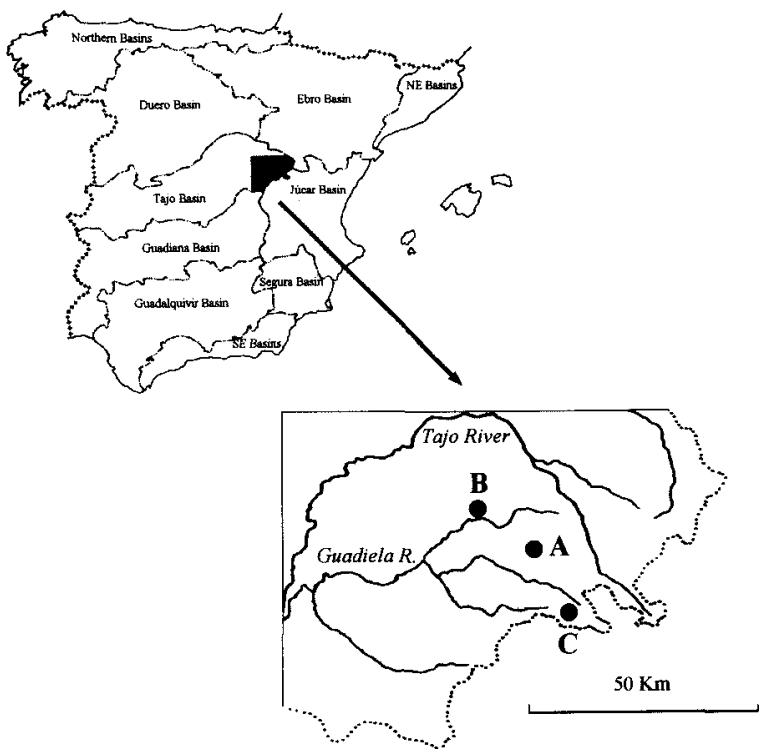

Figure 1. Location of the study area. Situación del área de estudio.

and discuss some of the limitations and advantages of its use as a quantitative sampling method in small streams.

\section{MATERIAL AND METHODS}

Three small creeks located on the headwaters of river Tajo basin (Cuenca, Central Spain) (Fig.1), harbouring white-clawed crayfish populations, were electrofished periodically from June 1997 to June 1998. Some selected physico-chemical and morphological characteristics of these creeks are shown in Table 1. Associated fish fauna was absent from creek C, whereas creek B supported a population of red roach, Rutilus arcasii (Steind.). In creeks A and B, individuals of brown trout (Salmo trutta L.) were occasionally caught.

A total of eleven representative sites where selected for sampling, four on creek A, four on creek B, and three on creek C. Sampling site limits were chosen searching for small natural obstacles to crayfish displacement, avoiding the need of closing the site with nets while sampling. 
Table 1. Some relevant characteristics of the creeks sampled. Algunas características destacables de los arroyos muestreados.

\begin{tabular}{llll}
\hline Creek & A & B & C \\
\hline Elevation $(m$ A.S.L. & 1360 & 900 & 1280 \\
Mean width $(\mathrm{m})$ & $2.05 \pm 0.38$ & $2.38 \pm 0.58$ & $2.74 \pm 1.15$ \\
Mean depth $(\mathrm{m})$ & 0.081 & 0.226 & 0.115 \\
Conductivity $(\mu \mathrm{SS} / \mathrm{cm})$ & $499 \pm 40.12$ & $457 \pm 2.65$ & $1638 \pm 73.54$ \\
Mean water temperature $\left({ }^{\circ} \mathrm{C}\right) \dagger$ & $8.82 \pm 0.199$ & $11.46 \pm 0.219$ & $10.82 \pm 0.268$ \\
Macrophyte cover $(\%) \ddagger$ & 0 & 5 & 35 \\
Dominant substrate & Gravel-Fine gravel & Boulder-Rock & Fine gravel-Mud \\
\hline
\end{tabular}

$\uparrow$ Daily mean (obtained from hourly values) for the period November 1997-November 1998

\$ Assessed in July I997

Surveys were carried on the same sites in June 1997, July 1997, August 1997, April 1998 and June 1998. Different circumstances prevented sampling all the sites in all surveys. Site length varied from 7.3 to $20.7 \mathrm{~m}$, while the sampled area was between 15 and $50 \mathrm{~m}^{2}$.

An ERREKA ${ }^{\text {TM }}$ commercial electrofishing unit, supplying rectified current and allowing variable voltage output, was used as a power source. Some slight modifications from standard technique for fish sampling in rivers were adopted. The anode was built in a square shape, allowing for better sweeping of the bottom and undersides of the banks, and was covered with a $5 \mathrm{~mm}$ mesh net, to allow catching swimming crayfish. Crayfish response to electrofishing is erratic (Burba, 1993; Westman et al.,1979), and includes a number of animals remaining narcotized or walking along the bottom, making very difficult catching them with a net without damage, so individuals detected in this way were handcaught, obviously with the power switched off and lifting the anode out from the water. Previous experience showed us that electrofishing efficiency on crayfish seem to improve using a low voltage output $(30-50 \mathrm{~V})$, and switching on and off the circuit for one or two seconds. The electrofishing team, comprising one person working with the anode, another catching crayfish in the bottom, and a third one helping from the bank, progressed upstream very slowly.

A minimum of three successive depletion efforts was made, but whenever the trend of the catches suggested it, an additional effort was carried out. In any case, the need for making a fifth effort was deemed unnecessary. In one survey a break-up of the power unit limited the number of efforts to two. The time spent in each effort was recorded in minutes.

In all crayfish collected, sex was determined when possible, caparace (rostrum-telson) length (CL) was measured with a Vernier caliper to the nearest $0.1 \mathrm{~mm}$, and weight was recorded to the nearest $0.1 \mathrm{~g}$ with a digital balance. In a systematic subsample of circa $20 \%$ of the individuals, total length (TL) was also recorded in the same way as caparace length. Cheliped loss and reproductive status (in females) were assessed. Crayfish were kept aside in different buckets until the end of all efforts, in aerated water and with enough stones for hiding. After measurement, all crayfish were returned alive to the water.

Population numbers and catchability estimates were obtained following the Carle \& Strub method. This maximum likelihood algorithm assumes a constant catchability in each effort, and was selected because of its statistical robustness (Carle \& Strub, 1978). When more than three efforts were available, estimations were also made following the generalized removal method described in Otis et al. (1978), which allows variations in the catchability, as included in the package CAPTURE. $\chi^{2}$ tests were then carried out to evaluate whether the distribution of the catch supported the hypothesis of a constant capture probability. Differences between population 
estimates obtained by both methods were checked with a $\mathrm{Z}$ test on the natural logarithms of the estimates (Skalski \& Robson, 1992).

Normality of data was tested by means of Kolmogorov-Smirnov tests prior to testing for differences using parametric ANOVAs or t-tests. Percentages and proportions were first arcsine transformed, and then were subjected to the same test for normality. Whenever significant departures from normality were observed, non-parametric tests were performed.

Analysis of size effects on catchability requires, for a particular survey, classing the catch into size groups and determining the catchability for each one. The use of a large number of groups would yield low numbers of individuals in some of them, giving less consistent values of this parameter and leading to frequent situations in which catchability could not be calculated. Instead, a different approach was chosen. Crayfish were classified into only two groups: "big" and "small", and the arbitrary size limit defining this division was shifted along the range of observed sizes. In this way, we were every time comparing only two groups, each one made up of a substantial number of individuals, and yet obtaining an overall perspective of the variation of catchability with size.

Unless otherwise stated, all the values are reported as mean \& standard error, with the number of observations in brackets. P-values are abbreviated as follows: $n s$ : non-significant $(\mathrm{p}>0.05)$; $*: 0.01 \leq \mathrm{p}<0.05 ;{ }^{* *}: 0.001 \leq \mathrm{p}<0.01 ; * * *: \mathrm{p}<0.001$.

Table 2. Relative speed developed by electrofishing teams during the first sampling effort over crayfish and fish populations (in $\mathrm{m}^{2} / \mathrm{min}$ (mean \pm standard error). Velocidad relativa de progresión de equipos en el muestreo de poblaciones de peces y cangrejos durante la primera pasada, en $\mathrm{m}^{2} / \min$ (media \pm error estándar).

\begin{tabular}{lcl}
\hline Population sampled & $\mathrm{N}$ & Relative speed $\left(\mathrm{m}^{2} / \mathrm{min}\right)$ \\
\hline Crayfish' & 56 & $0.75 \pm 0.049$ \\
Fish $^{2}$ & 16 & $22.5 \pm 2.94$ \\
\hline
\end{tabular}

(1) This study.

(2) ALONSO, unpublished data.

\section{RESULTS}

Upstream progression of the electrofishing team during the first capture effort was significantly slower (Kolmogorov-Smirnov test, $\mathrm{p}<0.001^{* * * *}$ ) than that made by the same team when sampling fish populations in the same area (Table 2), with a mean value of $0.752 \pm 0.0490 \mathrm{~m}^{2} / \min (\mathrm{n}=56)$. In $83.92 \%$ of the surveys three catch efforts were made, averaging 3.125 catch efforts per survey.

A total of 4823 crayfish were captured in 56 surveys. Catches went from 20 to a maximum of 464 crayfish in one survey at a particular site, averaging 86.13 captures. Caparace length ranged between $5.6-53.0 \mathrm{~mm}$, with a mean value of $23.14 \mathrm{~mm}$.

Mean overall catchability was $\mathrm{p}=0.603 \pm$ $0.0164(\mathrm{n}=56)$. Catches accounted for an average of $93.90 \% \pm 0.883 \%(n=56)$ of the estimated population number when using overall catchability. An ANOVA performed on overall catchability did not show significant differences between rivers $\left(\mathrm{MS}_{\text {error }}=0.014691, \mathrm{~F}_{2.53}=1.1631, \mathrm{p}=0.2094 n s\right)$ (Fig. 2). Catchability showed a gradual increase during 1997, followed by a decrease in the survey of April 1998, and a new increase in June 1998. Significant differences were found between the surveys carried out in August 1997 and June 1998 with both the surveys carried out in June 1997 and April 1998 (Fig. 3, Table 3).

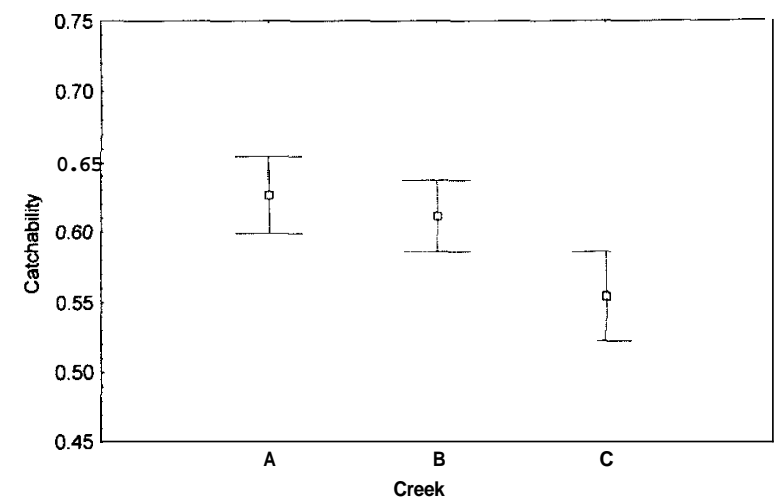

Figure 2. Difference in overall catchability between creeks (mean \pm S.E.). Diferencias en la cupturubilidad total entre arroyos (media \pm E.S.). 
Table 3. LSD tests on catchability between months. Contrastes de LSD sobre la capturabilidad entre meses

\begin{tabular}{|c|c|c|c|c|c|}
\hline Month & July & August & September & April & June \\
\hline June & $0.2006 n s$ & $0.0108 *$ & $0.0708 n s$ & $0.7567 n s$ & $0.0059 * *$ \\
\hline July & & $0.1838 n s$ & $0.4161 n s$ & $0.3448 n s$ & $0.1220 n s$ \\
\hline August & & & $0.8074 n s$ & $0.0275^{*}$ & $0.8228 n s$ \\
\hline September & & & & $0.1229 n s$ & $0.6741 n s$ \\
\hline April & & & & & $0.0161^{*}$ \\
\hline
\end{tabular}

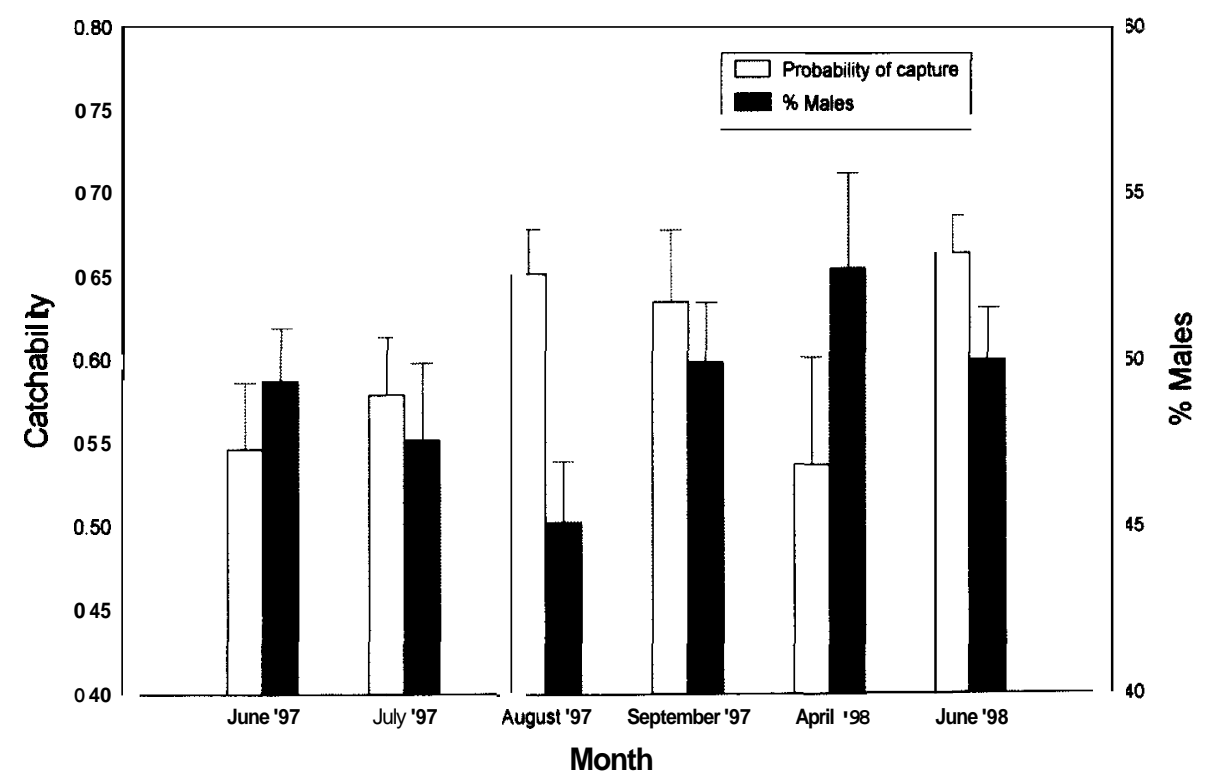

Figure 3. Temporal variation in overall catchability and sex composition of the catch (mean \pm S.E.). Variación temporal en la capturabilidad total y en la proporcidn de sexos en las cupturus (mediu \pm E.S.).

Table 4. Minimum least squares linear regression fitted between total length (TL) and caparace length (CL) for each sex. (TL= a + bCL, both in millimetres). Regresidn ajustada por mínimos cuadrados entre la longitud totul (TL)y la longitud de cefalotdrux (CL) para cada sexo. (TL= $a+b C L$, ambas en milímetros)

\begin{tabular}{lllll}
\hline Sex & $\mathbf{N}$ & $\mathbf{a} \pm$ S.E. $(\mathbf{a})$ & $\mathbf{b} \pm$ S.E. $(\mathbf{b})$ & $\mathbf{r}^{\mathbf{2}}$ \\
\hline Males & 422 & $2.785684 \mathrm{k} 0.165865$ & $1.962196 \pm 0.006202$ & 0.9958 \\
Females & 385 & $\mathbf{0 . 4 8 7 8 7 6 \pm 0 . 2 1 2 0 6 5}$ & $2.120067 \mathrm{k} 0.008643$ & 0.9937 \\
\hline
\end{tabular}


Estimated density ranged from 0.66 ind. $/ \mathrm{m}^{2}$ to $18.95 \mathrm{ind} . / \mathrm{m}^{2}$, while estimated relative biomass ranged between $2.92 \mathrm{~g} / \mathrm{m}^{2}$ to $120.36 \mathrm{~g} / \mathrm{m}^{2}$. Overall catchability was not found to be significantly correlated with either estimated density $\left(\mathrm{r}=0.1192, \mathrm{t}_{54}=0.8824, \mathrm{p}=0.3815 \mathrm{~ns}\right)$ or with estimated relative biomass $\left(\mathrm{r}=-0.0749, \mathrm{t}_{54}=-0.5519\right.$, $\mathrm{p}=0.5833 n s$ ).

In the eight surveys where more than three capture efforts were carried out, the generalized removal model was also used to estimate probabilities of capture and population numbers. In five cases, constant and variable probabilities of capture models gave the same results. In the other three cases, a variable catchability was found to fit significantly better the catch data. Estimated population numbers were found to be significantly different $\left(p=0.0003^{* * *}\right)$ in one out of these three cases.

\section{Influence of size}

Electric field effects are mainly function of the size of the individual, so to avoid the influence of sexual dimorphism, TL was employed instead of $\mathrm{CL}$ for size grouping. A linear regression was fitted to length data for each sex (Table 4), and predicted TL was used when no field data on a particular crayfish TL were available.

The pooled size distribution of the catch by months is shown in figure 4 . It should be noted that populations with different phenology and rates of growth are mixed up in this graph, which just tries to show the size structure of the catch and its influence on catchability. It should be carefully interpreted from a population dynamics perspective. Crayfish under $\mathrm{TL}=40 \mathrm{~mm}$ represented a high proportion $(31.25 \%)$ of the catch, showing two maxima during surveys in August 1997 (40.22\%) and April 1998(42.86\%). An ANCOVA on temporal variation of catchability using mean TL as covariate showed significant differences between the same surveys as already pointed out from ANOVA results.

Due to differences in crayfish growth between different rivers and to the difficulty for adequate assignation of age to individuals, which did not allow a classification based on population age structure, the analysis of size effect on catchabi-

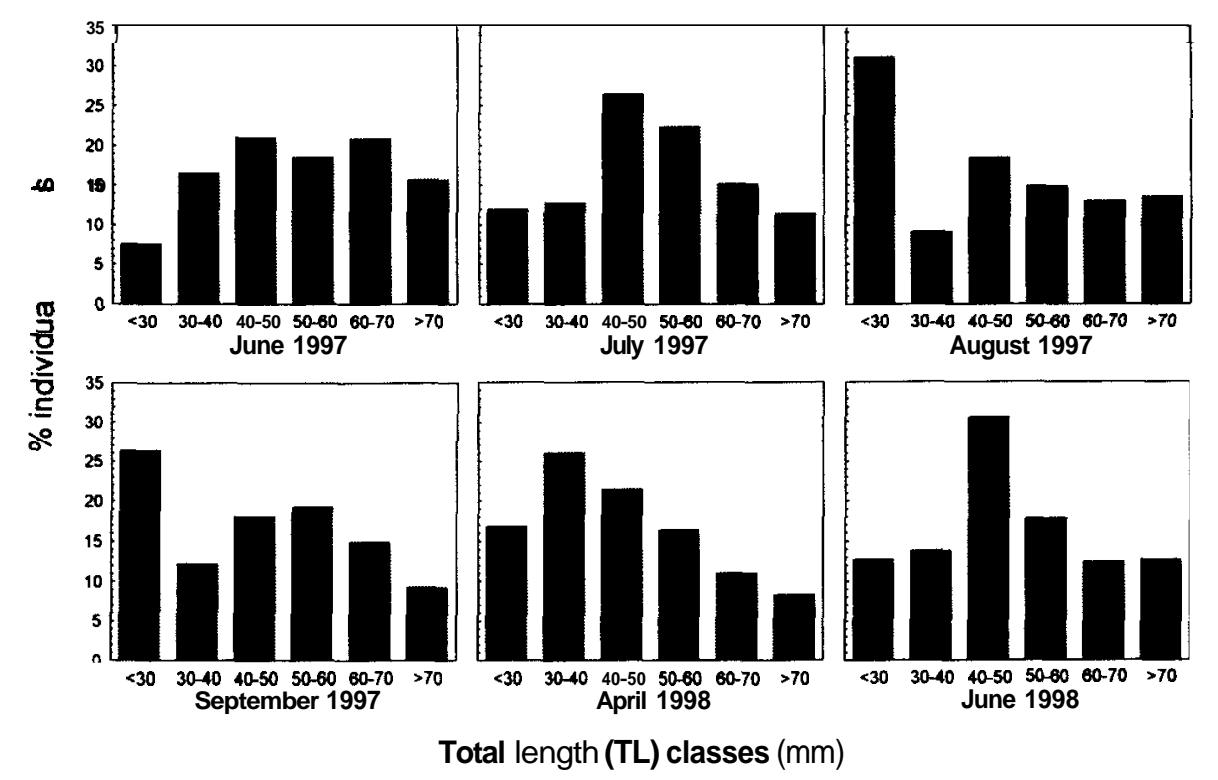

Figure 4. Temporal variation of the size frequency distribution of the catch. Variación estacional en la distribución de la cupturu por longitudes. 


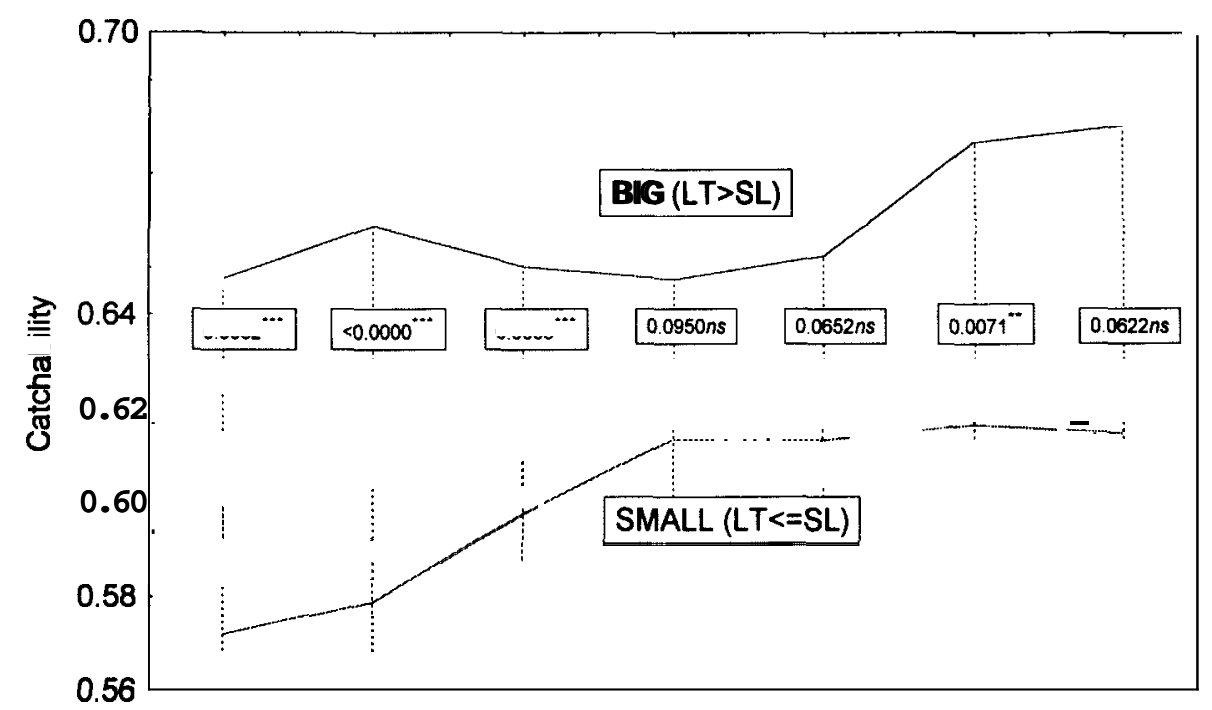

Figure 5 Effect of size on catchability. Crayfish caught in each survey were classed according to their total length (TL) into two groups: large $(\mathrm{TL}>\mathrm{SL}$ ) and small $(\mathrm{TL} \leq \mathrm{SL})$, using different values as size limit $(\mathrm{SL})$. Catchability for both groups in all surveys were compared by means of paired t-tests for each SL value. Figures represent $p$-values associated to each $\mathrm{SL}$ ( $\mathrm{df}=55$ except for $\mathrm{SL}=35$ and $\mathrm{SL}=65$, where $\mathrm{df}=54$ ) for different values of SL. $n s$ : non-significant; $*: 0.01 \leq \mathrm{p}<0.05 ; * *: 0.001 \leq \mathrm{p}<0.01 ; * * *: \mathrm{p}<0.001$. Efecto del tamaño sobre la capturabilidad. Se ha utilizado un límite de talla $(S L)$ que divide los cangrejos capturados en un inventario determinado en dos grupos en función de su longitud total $(T L)$ : grandes (TL $>S L$ ) y pequeños ( $T L \leq S L)$. Se muestran las probubilidades asociadas a contrastes de t para observaciones pareadas entre las probabilidades de captura de cangrejos grandes y pequeños (g.d.l. $=55$, salvo para $S L=35$ y SL=65, en que g.d.l. $=54$ )

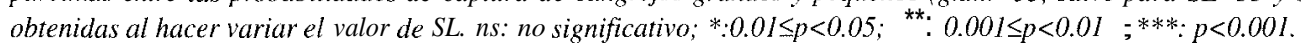

lity was performed splitting the catches of each survey into two size groups, small and large crayfish. As explained above, each of the groups included all individuals smaller or larger than a particular size limit (SL), which was shifted along the range of lengths observed. The catchability was then estimated for each group.

Five millimetre increments in SL showed a gradual but not significant increase in the catchability of both groups (Fig. 5 ) from a $\mathrm{SL}=35 \mathrm{~mm}$ to a $\mathrm{SL}=65 \mathrm{~mm}$. Scarcity of captures, leading to frequent situations in which the catchability could not be estimated, advised the exclusion from analysis of groups defined by a SL smaller than $\mathrm{TL}=35 \mathrm{~mm}$ or bigger than $\mathrm{TL}=65 \mathrm{~mm}$.

Catchability was found to be higher for large crayfish than for small crayfish for all the size limits analyzed. Paired comparison t-tests showed significant differences for size limits between $\mathrm{SL}=35 \mathrm{~mm}$ and $\mathrm{SL}=45 \mathrm{~mm}$, as well as for $\mathrm{SL}=60 \mathrm{~mm}$ (Fig. 5).

\section{Influence of sex and reproductive stage}

The observed sex ratio (SR) ranged from $\mathrm{SR}=0.533$ to $\mathrm{SR}=1.813$, with a mean value of $\mathrm{SR}=0.987 \pm 0.0353(\mathrm{n}=56)$; which did not differ significantly from a 1:1 ratio. The proportion of males in samples only differed significantly between August and April surveys (ANOVA on transformed percentages, $\mathrm{MS}_{\text {error }}=0.003987$, $\mathrm{F}_{1,50}=6.8143, \mathrm{p}=0.0119^{*}$ ) (Fig. 3).

Although catchability was slightly higher for females $(\mathrm{p}=0.637 \pm 0.0171 ; \mathrm{n}=56)$ than for males $(0.618 \pm 0.0182 ; n=56)$, a paired comparison t-test showed differences were not statistically significant $(\mathrm{t}=1.022, \mathrm{df}=55, \mathrm{p}=0.311 \mathrm{~ns})$. The analysis of 


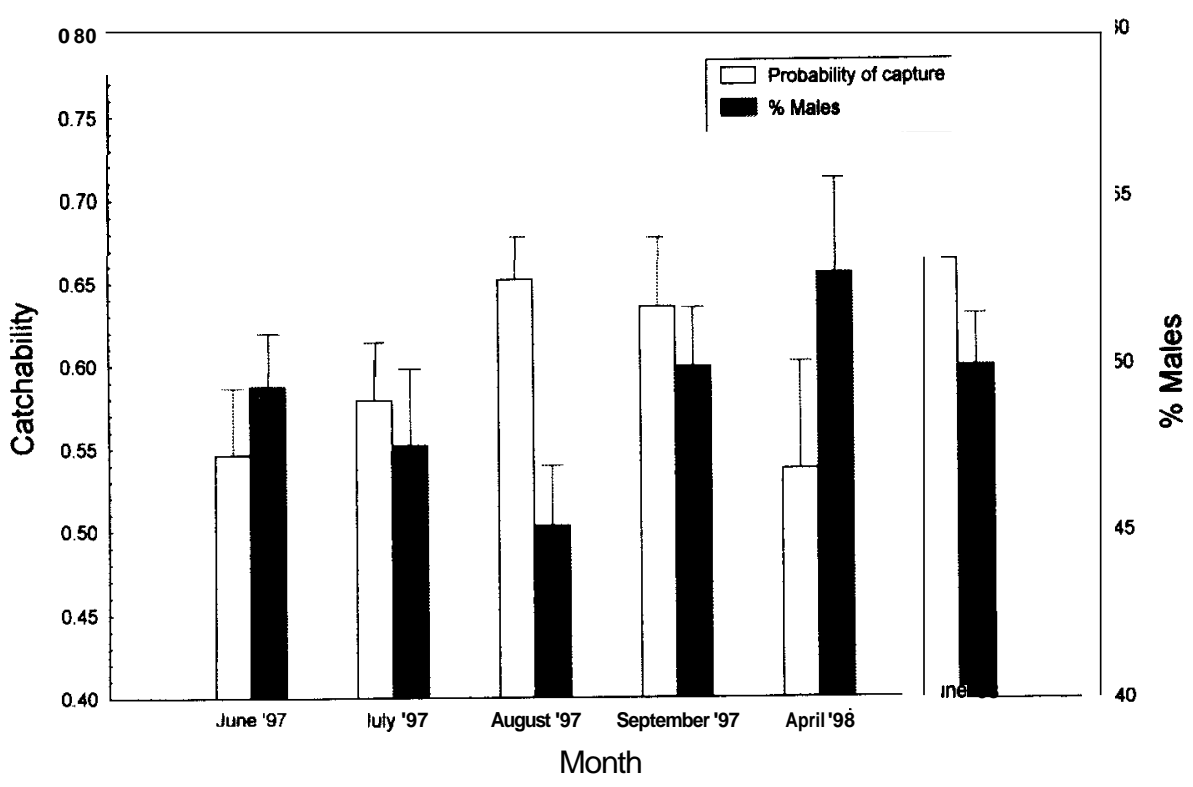

Figure 6. Influence of size on the degree of cheliped loss (means \pm S.E.). Influencia del tamaño en el grado de pérdida de quelípedos (medias \pm E.S.)

temporal variation of catchability by means of ANOVA did not show significant differences either for males $\left(\mathrm{MS}_{\mathrm{error}}=0.01766, \mathrm{~F}_{5,50}=1.6723\right.$, $\mathrm{p}=0.1586 \mathrm{~ns})$ or females $\left(\mathrm{MS}_{\text {error }}=0.016388\right.$, $\mathrm{F}_{5.50}=1.0534, \mathrm{p}=0.3973 \mathrm{~ns}$ ).

During April 1998 surveys 43 berried (ovigerous) females were captured. The smallest berried female measured $\mathrm{CL}=22.1 \mathrm{~mm}$. Berried females represented $46.74 \%$ of females longer than this length. The small number of berried females caught prevented the analysis of differences in catchability between berried and unberried females.

\section{Undesirable effects of electrofishing}

Some degree of cheliped loss was observed in $26.75 \%$ of the individuals, while $10.26 \%$ of the catch showed loss of both chelipeds.

Smaller crayfish were more prone to suffer cheliped loss. Analysis of the size distribution of cheliped loss (Fig. 6) showed a significant decrease with total length of both the proportion of crayfish showing cheliped loss and the fraction of these which lost both chelipeds (KruskalWallis test on transformed percentages; respectively $\mathrm{H}_{5.323}=14.4784, \mathrm{p}=0.0129^{*}$ and $\mathrm{H}_{5.273}=$ $\left.26.9680 \mathrm{p}=0.0001^{* * *}\right)$.

An ANOVA on transformed percentages did not show significant differences in the percentage of cheliped loss either between rivers $\left(\mathrm{MS}_{\text {error }}=0.013542, \mathrm{~F}_{2.53}=0.1689, \mathrm{p}=0.8450 \mathrm{~ns}\right)$ or between months of sampling $\left(\mathrm{MS}_{\text {erгоr }}=0.012239, \mathrm{~F}_{5.50}=1.8026, \mathrm{p}=0.1294 n s\right)$. To account for higher loss rate in smaller individuals, an ANCOVA using mean length of the catch as a covariate was performed. This analysis did not show significant differences between rivers, but differences were significant between months $\quad\left(\mathrm{MS}_{\text {error }}=0.00907, \quad \mathrm{~F}_{5,49}=3.46444\right.$, $\mathrm{p}=0.0092$ ). Significant differences were found between April 1998 surveys and those conducted in August and September 1997, and between June 1997 and August 1997. Nonetheless, percentage of cheliped loss was related in the opposite way to that expected from the observed effect of size on rate of loss (Fig. 7). The percentage of animals 
showing cheliped loss did not show any accumulative trend during the study (Fig. 7). No appreciable decrease was observed in either relative density or standing biomass.

Instant mortality due to electric shock was not recorded during sampling, but was observed to keep at very low levels. Two cases of cannibalism on recently moulted crayfish were observed during data collection. Thus, it was decided to keep soft crayfish aside from the rest during measurements. An odd number of crushed crayfish were collected from the bottom during or after some surveys, especially in the deeper reaches and in those where the bottom substrate was coarser.

\section{DISCUSSION}

Although Bernardo et al. (1997) did not state explicitly in their paper the catchability obtained for A. pallipes at river Azibo, they later reported a value of $\mathrm{p}=0.463$ (J.M. Bernardo, personal communication), which in the lower range of catchabilities reported in this paper. Catchability was not reported by Rabeni et al. (1997). Penczak \& Rodriguez (1990) found for shrimps slightly lower values $(p=0.53)$ than ours. Observed catchability is rather high, and can be considered satisfactory for population numbers estimation, as with $\mathrm{p}=0.6$ and three catch efforts around $90 \%$ of the estimated population is caught, also yielding reasonably accurate confidence intervals for the mean.

Perhaps the main criticisms to our methodology that can be put forward deal with the ability to maintain a constant effort in each pass and on the assumption of constant probability of capture. Although there are basic assumptions of most successive-depletion capture methods, they are usually difficult to fulfil.

The constant effort hypothesis was assessed by controlling the time invested in each pass. Time used per effort decreased noticeably after the first effort. It should be kept in mind that a non-negligible fraction of it was expended in collecting crayfish, particularly during the first effort.

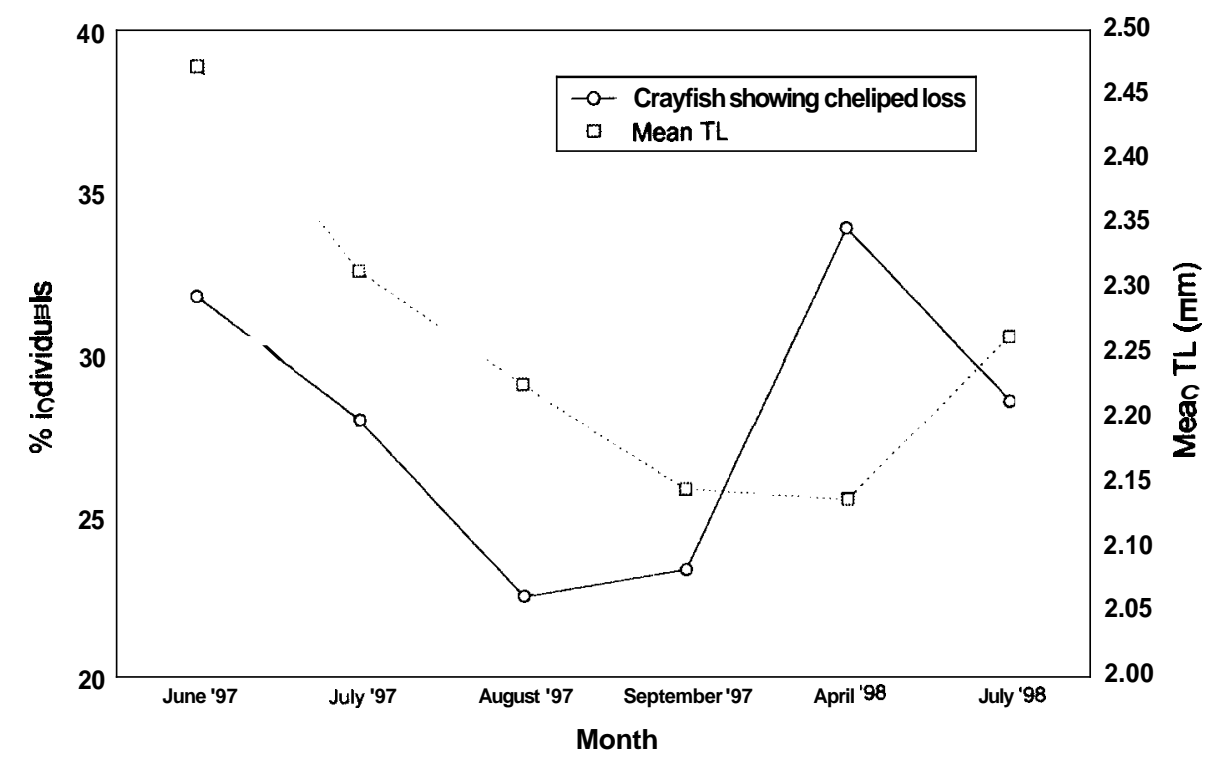

Figure 7. Temporal trend in the degree of cheliped loss, compared with the evolution of mean length of catches. Tendencia temporal en el grado de pérdida de quelípedos, comparado con la evolución temporal de la longitud media de las capturas. 
Nevertheless, it proved difficult to keep long sampling times (around 45-60 minutes) when in nearly $80 \%$ of the surveys the catches in the last effort were of ten or less crayfish. This also suggests an effective depletion of the population. The use of models based on a constant probability of capture for population size estimation seems an acceptable approach in view of the results obtained. Only in one out of eight surveys did results differ significantly when a variable model was applied. More data from surveys based on more than three efforts would be need to test this idea. Westman et al. (1979) pointed out the inability of crayfish to react to further electric stimulation after being narcotized. To test this, the catch of a particular effort was measured before next was carried out, in order to give crayfish in the creek some time to recover.

It is widely accepted that length is a primary factor influencing the catchability by electrofishing in fish (Zalewski \& Cowx, 1990), and the mechanisms involved in response to electric fields suggest that the same should be expected for crayfish. Also, smaller crayfish, and particularly young-of-the-year (YOY) can be difficult to identify and collect, especially when drifting among other large macroinvertebrates, resting immobile or hiding in the bottom, thus probably lowering their catchability. A different habitat selection by YOY than that by adults could also yield a different catchability for young and adults. For instance, YOY were found among macrophytes, where they are more difficult to catch. However, Demars (1979) did not appear to find size-dependent differences in the cathability of crayfish, as was pointed out by Penczak \& Rodriguez (1990) for shrimps. Nonetheless, their size analyses were not extensive. Also, Rabeni et al. (1997) failed to find significant changes in mean during within each survey as successive efforts were made. Some of the differences with our results could arise from the fact that only two surveys were analyzed, and that the size range of the catch was sensibly lower than ours (3-30 mm CL against 5-53 $\mathrm{mm} \mathrm{CL}$ ). In contrast, my work strongly suggests the existence of some sizedependent differences in crayfish catchability.
The approach followed, i.e. the setting of a variable size limit for grouping crayfish, allows a better study of the influence of size, avoiding the limitations posed by the small numbers which result from splitting the whole catch in a prefixed number of size classes. Dependence on size yields an asymptote towards both groups catchability (Fig. 5). The asymptote takes a value somewhat lower than the expected (i.e. the mean overall catchability) due to the effect of splitting the catches. It appears from my data that the use of at least two size groups, with a size limit in the range of 40-50 $\mathrm{mm}$ TL, should be considered for a better estimate of population size, particularly whenever any other meaningful population structure criterion, for example an accurate age estimation, is not available.

Penczak \& Rodriguez (1990) found that catchability was lower in lotic environments that in lentic areas. Hardly no stretch sampled here can be considered lotic, so I could not observe this kind of difference. Instead, singular structures, such as tangled submerged roots or particularly shaped blocks (i.e. big rocks leaving underside space), as well as heavy macrophyte growth, which can hold a considerable fraction of the crayfish in the reach, can influence the value of the catchability, and should be carefully and thoroughly fished.

On the other hand the lower values observed in June 1997 when compared with all samples collected later, except those of April 1998, may be partially explained as a result of the increased experience of the fishing team in crayfish sampling.

Typical estimates for white-clawed crayfish are usually under $10 \mathrm{ind} . / \mathrm{m}^{2}$ (i.e. Laurent, 1988), higher values being less frequent. The absence of small crayfish in surveys using methods other than electrofishing should also be noted. My data, coming from a relatively small area, cover a wide range of the values reported for the species from other parts of the world. The same can be said of biomass estimates, data of which are scarcer, although biomass values are much less affected by the absence of young crayfish in samples. The highest point biomass estimation, around 120 
$\mathrm{g} / \mathrm{m}^{2}$, was obtained in a prime habitat stretch: an isolated $25 \mathrm{~m}^{2}$ pool without fish predators, abundant Chara sp. marginal growth and easy to dig banks, in waters with high conductivity (creek C).

Westman et al. (1979) already pointed out that quantitative estimation of young of the year (YOY) crayfishes (less than $20 \mathrm{~mm}$ TL in their study) was not feasible with electrofishing, and is generally accepted that standard electrofishing underestimates $0^{+}$fish populations (see for example Hayes \& Baird, 1994). The same problem was found here. On the other hand, enough individuals of younger year classes were collected so as to allow the study of cohort progression, in particular for YOY. A clearly identifiable mode in size histograms was observed for this age-class as early as mid-July in the faster growth population (creek C), at about $\mathrm{CL}=9 \mathrm{~mm}$, hatching taking place in the area in the first days of June.

A high degree of cheliped loss remains as a major disadvantage of this technique. Changes in percentage of cheliped loss could not be explained solely in terms of variation in mean length of crayfish (Fig. 7). This suggest that more factors, such as moulting stage, can perhaps be related with the susceptibility to loose claws. It should be noted that the observed cheliped loss is not necessarily related with loss during the surveys. Drawing out conclusions from these data could be misleading as appendages lost prior to any survey would take some time to be completely replaced. Cheliped loss is known to slow the rate of growth of crayfish (Bowler \& Brown, 1977), affecting reproductive behaviour and maternal care (Holdich \& Reeve, 1988). Thus, it could constitute a source of error in population dynamics studies. In some instances, dealing as we are with endangered populations, this kind of damage can be straightforwardly considered as unacceptable. Bohl (1999) points out other disturbing effects of electrofishing, recording long displacements on half of the Astacus astacus tracked, following electrofishing episodes at high voltage $(300-600 \mathrm{~V})$, as well as anomalies in behaviour in some others. In my case, long displacements could have been prevented by the small length of the creek, continuously holding water, and to the existence of frequent small obstacles to crayfish movement. It also should be noted that voltage output used in this work is remarkably lower than that employed in other studies, which typically ranges between $300 \mathrm{~V}$ 600 V (e. g. Westman et al., 1979; Penczak \& Rodriguez, 1990; Bernardo et al., 1997). For the same shape of electric current, less damage to crayfish should be expected at lower voltage outputs. Further research on the mechanisms implicated on the response of crayfish to an electric field would be highly desirable, giving information on the type and shape of electric current less harming to crayfish. Nevertheless, the proportion of mutilated crayfish did not show any cumulative trend in my study. Although surveys were frequent, final values of biomass, in all but two of the eleven reaches sampled, were higher than those observed at the beginning of the study.

Electrofishing is a potentially harmful technique for the sampling team. Also, the methodology followed implies a degree of co-ordination, needed for the simultaneous lifting up of the electrode and the hand-catching of static crayfishes. Indeed this sampling method contravenes safety rules in some countries (e. g. United Kingdom, Finland, see Cowx (1990) for details), which also ban, in some cases, the use of dip-net electrodes. As far as I know, there are no regulations dealing with electrofishing in Spain yet. The low voltage and intensity employed in this study diminishes somehow the risk in comparison with the standard conditions in which electrofishing is commonly carried out. I have not found an alternative efficient way of catching motionless individuals without damaging them. This way of collecting crayfish limits the efficiency to clear enough, waist-deep or shallower waters, where turbidity settles quickly enough after the passage of the electrofishing team.

Its much lower speed when compared with fish sampling, which makes it an expensive technique, as well as the already mentioned undesirable side-effects, may restrict the use of electrofishing. I have also used this technique when a qualitative sample is needed in times of low cray- 
fish activity, or when a smaller bias in sex and length of the captured individuals when compared with traditional sampling methods, such as traps, is desired. The high proportion of animals caught with respect to the estimated population, in particular those of the larger sizes classes, can make it a valuable technique for the control of undesired crayfish populations in some environments. We have begin using it on a population of the exotic signal crayfish Pacifastacus leniusculus (Dana) in a small river where the species, surreptitiously stocked, menaces the future of a highly valuable population of native crayfish. It can also yield valuable results when the catch of a large fraction of the population is desired for other purposes (e. g. for mark-recapture experiments).

On the whole, my data suggest that electrofishing can still be regarded as a useful tool for the management tool of native crayfish populations in Spain, as most of them are similar to those described in this work (Alonso et al., 2000).

\section{ACKNOWLEDGEMENTS}

I would like to thank very specially Mari Cruz Cano, Tomás Marín and Orencio Sanchez for their enthusiastic help in field sampling. Assistance from the staff at the Servicio de Medio Ambiente Natural of Cuenca, in particular M. Bueno, J.Miota, J.I. Nicolás and A. Sequi, is gratefully acknowledged. F.Hervella (Centro de Investigación de Lourizan), lent me his software PEZ for population parameters estimation. This work was supported by the National Crop and Food Research R+D Programme (INIA n ${ }^{\circ}$ SC-96006). Additional financial support was given by the Servicio de Investigacibn Agraria of the Junta de Comunidades de Castilla-La Mancha.

\section{REFERENCES}

ABRAHAMSSON, S. 1966. Dynamics of an isolated population of the crayfish Astacus astacus Linné. Oikos, 17: 96-107.
ABRAHAMSSON, S. 1983. Trappability, locomotion and diel pattern of activity of the crayfish Astucus astacus and Pacifastacus leniusculus Dana. In: Freshwater Crayfish V. Papers from the 5th International Symposium on Freshwater Crayfish. C.R. Goldman (ed.): 239-253. Davis, California.

ALMAÇA, C. 1989. On the biology of Northeastern Portuguese populations of Austropotamobius pallipes (Lereboullet, 1858). Arquivos do Museu Bocage, I (29): 419-428.

ALONSO, F., C. TEMIÑO \& J.DIÉGUEZURIBEONDO. 2000. Status of the white-clawed crayfish, Austropotamobius pallipes [Lereboullet, 1858], in Spain: Distribution and legislation. Bulletin Française de la Pêche et de la Pisciculture, 347: 31-54.

BERNARDO, J.M., M. ILHEU \& A.M. COSTA 1997. Distribution, population structure and conservation of Austropotamobius pallipes in Portugal. Bulletin Française de la Pêche et de la Pisciculture, 347: 617-624.

BOHL, E. 1999. Motion of individual noble crayfish Astacus astacus in different biological situations: In-situ studies using radio telemetry. In: Freshwater Crayfish 12. Proceedings of the $12^{\text {th }}$ Symposium of the International Association of Astacology, Augsburg, Germany. Keller M., M.M. Keller, B. Oidtmann, R. Hoffman \& G. Vogt (eds.): 677-787. Weltbild Verlag.

BROWN, D.J. \& J.M. BREWIS. 1978. A critical look at trapping as a method of sampling of Austropotarnobius pallipes (Lereboullet) in a mark and recapture experiment. In: Freshwater Crayfish IV. Papers from the 4th International Symposium on Freshwater Crayfish. P.J. Laurent (ed.): 159164. Thonon-les-Bains, 1977. INRA.

BOWLER,K. \& D.J. BROWN.1977. Some aspects of the growth in the British freshwater crayfish Austropotamobius pallipes pallipes. In: Freshwater Crayfish III. Papers from the 3rd International Symposium on Freshwater Crayfish. .O. Lindquist (ed.): 295-308. University of Kuopio.

BURBA, A. 1993. Investigation of the effects of anthropogenic factors on crayfish behavioural reactions. In Holdich,D.M.\& Warner,G.F.(eds.): Freshwater Crayfish IX. Papers from the $9^{\text {th }}$ International Symposium of Astacology, Reading, England. University of Southwestern Louisiana: 466-476.

CARLE, F.L. \& M.R. STRUB. 1978. A new method for estimating population size by removal data. Biometrics, 34: 621-630. 
CARRAL, J.M., J.D. CELADA, J. GONZÁLEZ, M. SAÉZ-ROYUELA, V.R. GAUDIOSO, R. FERNÁNDEZ \& C. LÓPEZ-BAISSON. 1993. Wild freshwater crayfish populations in Spain: current status and perspectives. In: Freshwater Crayfish IX. Papers, from the $9^{\text {th }}$ International Symposium of Astacology, Reading, England. Holdich,D.M.\& Warner,G.F. (eds.): 158-162. University of Southwestern Louisiana.

COWX I.G. (ed.) 1990. Developments in electric fishing. Fishing News Books. Blackwell Science Publications, Oxford. 358 pp.

DEMARS, J.J. 1979. Premières donnees sur les populations d'écrevisses de quelques cours d'eau du Haute Bassin Loire-Allier. In: Freshwater Crayfish IV. Papersfrom the $4^{\text {th }}$ International Symposium of Astucology, Thonon-Les-Buins, France. Laurent, P.J. (ed.): 165-174. INRA.

DIEGUEZ-URIBEONDO, J, A. RUEDA, E. CASTIEN \& J.C. BASCONES. 1997a. A Plan of Restoration in Navarra for the native freshwater species of Spain, Austropotamobius pallipes. Bulletin Française de la Pêche et de la Pisciculture, 347: 625-638.

DIÉGUEZ-URIBEONDO,J, C. TEMINO \& J.L. MUZQUIZ. 1997b. The crayfish plague fungus (Aphanomyces astaci) in Spain. Bulletin Française de la Pêche et de la Pisciculture, 347: 753-763.

FENOUIL, E. \& P. LEGER. 1988. Sélectivité des techniques de capture chez les populations d'Austropotamobius pallipes. In: Freshwater Crayfish VII. Papers from the 7 th International Symposium of Astucology. P.Goeldlin (ed.): 295302. Lausanne, Switzerland, 1987. Musee Zoologique Cantonal. Lausanne.

FIÈVET, E., L. TITO DE MORAIS \& A. TITO DE MORAIS. 1996. Quantitative sampling of freshwater shrimps: comparison of two electrofishing procedures in a Caribbean stream. Archiv. Hydrobiol.. 138 (2): 273-287.

GUTIÉRREZ-YURRITA, P.J., c. ILHEU, M., MONTES \& J.M. BERNARDO. 1997. Morphometrics of red swamp crayfish from a temporary marsh (Doñana National Park, SW Spain) and a temporary stream (Pardiela Stream, S Portugal). In: Freshwater Crayfish 11. Papers from the $11^{\text {th }}$ International Symposium of Astucology, Thunder Bay, Ontario. Momot, W.T. (ed.): 384-393.

HAYES, J. W. \& D.B. BAIRD. 1994. Estimating relative abundance of juvenile brown trout in rivers by underwater census and electrofishing. New Zealand
Journal of Marine and Freshwater Research, 28 (3): 243-253.

HOLDICH, D.M. \& REEVE,I.D. 1988. Functional morphology and anatomy. In: Freshwater Crayfish: Biology, management and exploitation. Holdich, D.M. \& Lowery, R.S. (eds.): 11-51. Croom Helm.

HOGGER, J.B. 1988. Ecology, population biology and behaviour. In: Freshwater crayfish: Biology, management and exploitation. Holdich,D.M. \& Lowery, R.S. (eds.): 114-144. Croom Helm, London.

ILHEU, M. \& J.M. BERNARDO. 1997. Life history and population biology of red swamp crayfish, Procambarus clarkii, in a Mediterranean reservoir. In: Freshwater Crayfish 11. Papers from the $11^{\text {th }}$ International Symposium of Astucology, Thunder Bay, Ontario. Momot,W.T. (ed.): 54-59.

JESTIN, J. M. 1979. Croissance et developpement de l'ecrevisse americaine, Orconectes limosus (Rafinesque), dans le lac de Creteil (Val de Marne) (France). In: Freshwater Crayfish IV. Papers from the $4^{\text {th }}$ International Symposium of Astucology, ThononLes-Bains, France. INRA. Laurent, P.J. (ed.): 65-72.

LAURENT, P.J. 1988. Austropotamobius pallipes and A. torrentium, with observations on their interaction with other species in Europe. In: Freshwater Crayfish: Biology, management and exploitation. Holdich, D.M. \& Lowery, R.S. (eds.): 341-364. Croom Helm.

OTIS, D.L., K.P. BURNHAM, G.C. WHITE \& J.D. ANDERSON. 1978. Statistical inference for capture data on closed animal populations. Wildlife Monographs, 62: 1- 135.

PENCZAK T. \& G. RODRIGUEZ. 1990. The use of electrofishing to estimate population densities of freshwater shrimps (Decapoda, Natantia) in a small tropical river, Venezuela. Archiv. Hydrobiol., 18 (4): 501-509.

PRINGLE, C. M. \& G.A. BLAKE. 1994. Quantitative effects of atyid shrimp (Decapoda: Atyidae) on the depositional environment in a tropical stream: use of electricity for experimental exclusion. Can. $J$. Fish. Aquat. Sci., 51: 1443-1450.

RABENI , C.; K.J. COLLIER, S.M. PARKYN \& B.J. HICKS. 1997. Evaluating techniques for sampling stream crayfish (Paranephrops planifrons). New Zealand J. Mar: Freshw. Res. 31: 693-700.

SKALSKI, J.R. \& D.S. ROBSON. 1992. Techniques for wildlife investigations design and analysis of capture data. Academic Press: 28-29. 
TEMINO, C., J.D. CELADA, J.M. CARRAL \& R. FERNANDEZ. 1987. Estudio de las poblaciones astacicolas en los rios de la provincia de Burgos.Perspectivas. In: Jornadas de Estudio del Cangrejo de Rio. Informe Técnico $n^{\circ} 4$. Gobierno Vasco. Departamento de Agricultura y Pesca. Vitoria: 87-109.

WESTMAN, K., J. SARKAA, M. PURSIANEN \& O. SUMARI. 1986. Population structure and gut contents of the crayfish Astacus astacus in two Finnish rivers. In: Freshwater Crayfish VI. Papersfrom the $6^{\text {th }}$ International Symposium of Astacology, Lund. Brinck, P. (ed.): 166-177. IAA, Lund

WESTMAN, K., O. SUMARI \& M. PURSIANEN. 1979. Electric fishing in sampling crayfish.. In: Freshwater Crayfish IV. Papers from the $4^{\text {th }}$ International Symposium of Astacology, ThononLes-Bains, France. Laurent, P.J. (ed.): 252-255. INRA.

WESTMAN, K., R. SAVOLAINEN \& M. PURSIANEN. 1993. A comparative study on the growth and moulting of the noble crayfish, Astacus astacus (L.), and the signal crayfish, Pacifastacus leniuscu- lus (Dana), in a small forest lake in southern Finland. In: Freshwater Crayfish IX. Papers from the $9^{\text {th }}$ International Symposium of Astacology, Reading, England. Holdich, D.M.\& Warner, G.F. (eds.): 466-476. University of Southwestern Louisiana.

WESTIN, L. \& R. GYDEMO.1995. The proportion of mature females of the noble crayfish Astacus asta$c u s$, in ponds and under indoor conditions and the effect of trappability. In: Freshwater Crayfish VIII. Papers 8th International Symposium of Astacology. R.P. Romaire (ed.): 157-169. Baton Rouge, Louisiana, USA, 1990. Louisiana State University.

WHITE,G. C., D.R. ANDERSON, K.P. BURNHAM \& D.L. OTIS. 1982. Capture-recapture and removal methods for sampling close populations. Los Alamos National Laboratory, New Mexico. $235 \mathrm{pp}$.

ZALEWSKI,M. \& I.G. COWX. 1990. Factors affecting the efficiency of electric fishing. In: Fishing with electricity: Applications in freshwater fisheries management. Cowx, I.G. \& Lamarque,P. (eds.): 89-112. Fishing News Books, Oxford. 